\title{
Experimental Studies on Earthen Architecture Sites Consolidated with BS Materials in Arid Regions
}

\author{
Dong Zhao,, ${ }^{1}$ Wei Lu, ${ }^{2}$ Yulan Wang, ${ }^{2}$ Xiaofei Mao, ${ }^{1}$ Yu Ai, ${ }^{3}$ and Haotian Jiang ${ }^{2}$ \\ ${ }^{1}$ School of Science, Xian University of Architecture \& Technology, Xi'an, Shaanxi 710055, China \\ ${ }^{2}$ School of Civil Engineering, Xian University of Architecture \& Technology, Xian, Shaanxi 710055, China \\ ${ }^{3}$ Xian Aerorspace Remote Sensing Data Technology Co., Ltd., Xi'an, Shaanxi 710100, China
}

Correspondence should be addressed to Wei Lu; 281081454@qq.com

Received 17 November 2015; Accepted 14 February 2016

Academic Editor: Charles C. Sorrell

Copyright (C) 2016 Dong Zhao et al. This is an open access article distributed under the Creative Commons Attribution License, which permits unrestricted use, distribution, and reproduction in any medium, provided the original work is properly cited.

\begin{abstract}
This paper takes the preservation works on the archaeological sites of Gaochang Ruins, Xinjiang, as background. Based on the soil characteristics analysis on the archaeological sites, experimental studies were conducted on the consolidation effect of the BS-10 consolidation material on the archaeological sites of adobe and rammed earth. The results showed the following:, after consolidation, the wind erosion resistance of the soil on the archaeological sites was substantially increased, and the wind erosion modulus was reduced by 5 8 times; the soil exhibited fine grid structure and significantly reduced degree of permeability, while still maintaining the moisture exchange between inside and outside the soil; there is excellent ageing resistance; the resistance to freezing and thawing was closely related to the soil water content and had little influence in arid regions; the water resistance was improved and could satisfy the requirements for consolidating the sites in arid regions; the unconfined compressive strength was improved moderately, which was the key direction of improvement in the future, and the consolidated soil did not form duricrust on the surface and had good bonding strength with the internal parts. The BS-10 material can meet the consolidation requirements for the earthen archaeological sites in arid regions of northwest China.
\end{abstract}

\section{Introduction}

The earthen architecture archaeological sites are the architectural remains of the earthen architecture built by ancient people despite hundreds of years of erosion [1-5] and represent the historical and cultural styles and architectural technique level during that period, and therefore they are having significant scientific and cultural value [6]. But, unfortunately, due to lack in preservation, most sites have been permanently damaged, and most of the existing sites are also in the state of danger and urgently require preservation [7-10].

With the efforts of archaeologists, the researches on soil consolidation material of the earthen sites have been developed rapidly in practice [11-16], but the relevant theoretical and experimental studies are still imperfect. This paper will discuss the experimental studies on the applicability of BS10 series consolidation materials (silicone-modified acrylic resin emulsion, hereinafter referred to as modified acrylic emulsion) in preservation works on the archaeological sites of Gaochang Ruins (Figure 1), which provides a reference for similar works on preservation of archaeological sites in arid regions.

\section{Soil Characteristics Analysis}

The different types of soil in different regions vary in the soil structure and the mineral composition, the structural resistance to damage, and the disease characteristics [17-19]. For more pertinent consolidation and preservation of earthen archaeological sites, it is necessary to conduct experimental studies on the characteristics of materials on the archaeological site, and the appropriate consolidation materials have to be selected.

The Gaochang Ruins is mainly built with adobe or rammed earth, of which raw soils are generally taken locally. During this test, a total of 35 groups of soil samples are taken, including 15 groups of samples of rammed earth, 10 groups of new and old adobes, respectively, and the weathered layers 


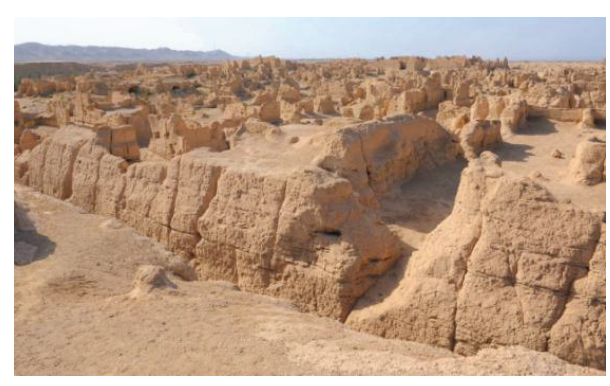

FIGURE 1: Gaochang Ruins panoramic view.

of the surface and the internal parts were taken as several groups of samples, respectively. The undisturbed adobes were sampled from the south row of houses in Big Buddha Temple of Gaochang Ruins, and the rammed earth samples were taken from the west city wall.

2.1. Microstructure. Analyze the content of microcomposition of the soil samples, among which the content of debris was gained by weighting the soil from manual removal on the samples surface, the content of clay and calcite was gained by XRD analysis, and the porosity was calculated by micro CT method. The result is presented in Table 1.

As can be seen, the main composition of the adobe and rammed earth sample is clay; the porosity in the rammed earth was rather high, possibly due to the limitations by the ancient manual soil ramming and construction technology level, or also possibly due to improper moisture control when ramming, which will affect the permeability of the soil on the archaeological sites directly; the debris was mostly on the soil surface, and its content in the adobe sample was high, mainly due to the persistent wind and rain erosion. The consolidation of wind erosion resistance was actually the consolidation of the weathered layer in the soil surface. The depth of the consolidation materials should better be penetrated $2-3 \mathrm{~cm}$ into the unweathered soil, and this index was the key factor to determine the diameter of single-hole permeability and its grout amount.

2.2. Chemical Analysis and Easily Dissolved Salts Analysis. This experiment is based on "Methods for Chemical Analysis of Cement" [20], the contents of $\mathrm{Na}_{2} \mathrm{O}$ and $\mathrm{K}_{2} \mathrm{O}$ were measured by atomic absorption spectrometry (AAS) method and the loss on ignition was measured by gravimetric method, and the others were measured by volumetric analysis method. The chemical analysis was made on the samples of the undisturbed soil for rammed earth and the undisturbed soil for adobes. Taking into account the differences in the soil samples, 3 groups were replicated, and the values were averaged for each item [21], of which analysis results are as shown in Table 2.

Analysis on soluble salt was measured referring to "Standard for Soil Test Method" [22]; the moisture contents of rammed earth and adobe sample are $2.47 \%$ and $2.03 \%$ relatively. $\mathrm{HCO}_{3}{ }^{-}$and $\mathrm{Cl}^{-}$were measured by volumetric analysis method, $\mathrm{SO}_{4}{ }^{2-}$ was measured by turbidimetry method, and
TABLE 1: Microscopic observation results of soil material.

\begin{tabular}{lcccc}
\hline Soil samples & Clay/wt\% & Calcite/wt\% & Debris/wt\% & Porosity/\% \\
\hline Rammed earth & $30 \sim 40$ & $20 \sim 30$ & $15 \sim 20$ & $15 \sim 20$ \\
Old adobe & $40 \sim 50$ & $20 \sim 30$ & $15 \sim 25$ & $<5$ \\
New adobe & $50 \sim 60$ & $15 \sim 20$ & $20 \sim 30$ & $<3$ \\
\hline
\end{tabular}

the other ions were measured by AAS method. The analysis results of easily dissolved salt are as shown in Table 3.

As can be seen from the test results, the samples of rammed earth and adobe are basically of the same chemical composition, and the materials are taken locally. The two soil samples feature $\mathrm{SiO}_{2}$ in content of nearly $60 \%$, greater sediment concentration, and poor bonding properties, as well as loose soil structure. During consolidation in the late period, care should be exercised to strengthen the connection strength between soil particles, making it cemented as a whole. The two types of materials are in rather higher level of chloride content, but as most of the rammed earth were constructed near the ground, the capillary effects of the underground water and air evaporation were strong to make the chloride salt easier to be gathered; the chloride content in the rammed earth is higher than that in the adobe. When the soil is dry, these salts fill the voids between the soil particles and exert the effect of cementing the soil; when there is water infiltration, these salts are dissolved and ionized and gradually migrated to the soil surface with the evaporation of water, destroying the original soil structure, so that the salts are accumulated on the soil surface and form into hard shell. The soil internal and external strengths are different, thereby easily leading to cracking, spalling, and other damage.

2.3. Physical Properties of Undisturbed Soil. The collected soil samples are tested to obtain the physical properties of undisturbed soil. The experiment method is based on "Methods for Chemical Analysis of Cement" [20]; the parameters of wet bulk density, moisture content, dry bulk density, and liquid and plastic limit were achieved by indoor experiment and other parameters were obtained by calculation of measured parameters, as shown in Table 4.

The physical properties of rammed earth and adobe are substantially similar, except that the moisture content of the adobe is relatively lower than that of the rammed earth, mainly due to the difference in the construction technology. In addition, the wheat straw and other reinforcement materials in the adobe have certain impact on the moisture content.

2.4. X-Ray Analysis. The X-ray analysis is the X-ray diffraction formed by crystals. It is a method for analysis of the spatial distribution of atoms inside the matter and capable of qualitative and quantitative analysis [23].

The rammed earth and adobe materials are crushed and impurities and organic matter were removed therein, placed indoors for $30 \mathrm{~d}$, and, after air drying, finely ground for Xray diffraction test. The " $K$ value" method [24] is used to do semiquantitative analysis, taking corundum $\left(\alpha-\mathrm{Al}_{2} \mathrm{O}_{3}\right)$ as reference. The results are as shown in Figure 2. 
TABLE 2: Chemical analysis results of undisturbed soil samples of rammed earth and adobes (wt\%).

\begin{tabular}{lccccccccc}
\hline Soil samples & $\mathrm{SiO}_{2}$ & $\mathrm{Al}_{2} \mathrm{O}_{3}$ & $\mathrm{CaO}$ & $\mathrm{Fe}_{2} \mathrm{O}_{3}$ & $\mathrm{Na}_{2} \mathrm{O}$ & $\mathrm{MgO}$ & $\mathrm{K}_{2} \mathrm{O}$ & Loss on ignition & Total \\
\hline Rammed earth & 58.3 & 14.1 & 6.5 & 4.7 & 3.1 & 2.3 & 2.0 & 7.0 & 98.9 \\
Undisturbed soil & 58.8 & 14.3 & 5.8 & 5.0 & 3.1 & 2.1 & 1.9 & 7.5 & 99.35 \\
\hline
\end{tabular}

TABLE 3: Easily dissolved salt breakdown results of undisturbed soil samples of rammed earth and adobes.

\begin{tabular}{lcccccccccc}
\hline Soil samples & Unit & $\mathrm{HCO}_{3}{ }^{-}$ & $\mathrm{Cl}^{-}$ & $\mathrm{SO}_{4}{ }^{2-}$ & $\mathrm{Ca}^{2+}$ & $\mathrm{Mg}^{2+}$ & $\mathrm{Na}^{+}$ & $\mathrm{K}^{+}$ & $\mathrm{Moisture} \mathrm{content}^{2}$ \\
\multirow{2}{*}{ Rammed earth } & $\mathrm{mmol} / \mathrm{kg}$ & 5.53 & 73.82 & 2.34 & 21.35 & 6.29 & 26.70 & 2.28 & 2.47 \\
& $\%$ & 0.034 & 0.262 & 0.023 & 0.085 & 0.015 & 0.061 & 0.009 & - \\
\hline \multirow{2}{*}{ Adobes } & $\mathrm{mmol} / \mathrm{kg}$ & 4.90 & 11.90 & 2.47 & 1.88 & 1.08 & 12.22 & 1.95 & 2.03 \\
& $\%$ & 0.030 & 0.042 & 0.024 & 0.008 & 0.003 & 0.028 & 0.008 & - \\
\hline
\end{tabular}

TABLE 4: Physical and mechanical parameters of undisturbed soil of rammed earth and adobe.

\begin{tabular}{|c|c|c|c|c|c|c|c|c|c|}
\hline $\begin{array}{l}\text { Undisturbed } \\
\text { soil type }\end{array}$ & $\begin{array}{c}\text { Wet bulk } \\
\text { density } \\
\mathrm{g} / \mathrm{cm}^{3}\end{array}$ & $\begin{array}{c}\text { Moisture } \\
\text { content } \\
\% \\
\end{array}$ & $\begin{array}{c}\text { Dry bulk } \\
\text { density } \\
\mathrm{g} / \mathrm{cm}^{3}\end{array}$ & $\begin{array}{c}\text { Liquid } \\
\text { limit } \\
\%\end{array}$ & $\begin{array}{c}\text { Plastic limit } \\
\%\end{array}$ & $\begin{array}{l}\text { Specific } \\
\text { gravity }\end{array}$ & Void ratio & $\begin{array}{c}\text { Porosity } \\
\%\end{array}$ & $\begin{array}{c}\text { Saturation } \\
\%\end{array}$ \\
\hline $\begin{array}{l}\text { Rammed } \\
\text { earth }\end{array}$ & 1.903 & 2.707 & 1.853 & 0.241 & 4.606 & 2.675 & 0.444 & 0.307 & 21.60 \\
\hline Adobe & 1.733 & 1.778 & 1.702 & 0.238 & 4.605 & 2.675 & 0.527 & 0.364 & 20.66 \\
\hline
\end{tabular}

Note: most of pores are intergranular pores, mainly in middle size $(0.016-0.004 \mathrm{~mm})$ and in small size $(0.004-0.001 \mathrm{~mm})$. Saturation means the ratio between the volume of water and the volume of pores in the soil. Void ratio means the percentage between the volume of pores and the whole volume of the soil sample in natural state. Liquid limit and plastic limit mean the upper limit and lower limit of moisture content when the soil particles are in plastic state.

In Figure 2, $0.426 \mathrm{~nm}$ and $0.335 \mathrm{~nm}$ are the characteristic diffraction peaks of the quartz and $0.320 \mathrm{~nm}$ and 0.303 are relatively the characteristic diffraction peaks of feldspar and calcite. Based on the diffraction peak position of each phase, and comparing them with the standard cards of JCPDS, the quality percentage of each material in the soil sample can be achieved by " $K$ value" method as follows: the mineral composition for samples of rammed earth includes the quartz and feldspar in contents of about $40 \%$, respectively, the calcite in content of $11 \%$, and small amount of other minerals; the adobe includes quartz in content of $51 \%$, calcite in content of $10 \%$, feldspar in content of $27 \%$, and small amounts of other minerals.

The adobe and rammed earth are substantially similar in mineral composition, possibly with slight difference due to the production process, indicating that the soils were taken from the local area at the time of construction, and other materials were not added to the soil body to change the characteristics of soil.

Energy Dispersive Spectrometer (EDS) is a kind of technology [25] that can analyze the elements of samples according to the peak intensities and energy eigenvalue using the $\mathrm{X}$ line theory of elements energy characteristics. Experiment methods referred to [26], and the results of the adobe samples are as shown in Figure 3.

Determine the element types according to the energy value of individual peak and analyze the element content according to the peak intensities. Referring to the analysis result of XRD, the quality percentage of each element can be achieved and they are basically coincided with the complete chemical analysis results, among which the silicon content is the highest in the soil. When selecting consolidation material, the consolidation material selected should be of the same mineral composition and distribution as the soil material, so that the original structure and properties of the soil are not changed as much as possible, and the consolidation materials must be protected from harmful chemical reactions with the minerals in the soil lest damage to the site.

\section{Consolidation Material and Sample Preparation}

Based on the said analysis on the soil properties of the sites, and combined with the purpose and requirements of the preservation of the earthen architecture sites, this paper selected the BS-10 antiweathering stabilizer, used the preservation works of the ruins site in Gaochang County, and studied the consolidation effect on its earthen architecture sites, thereby providing a reference for similar consolidation works.

3.1. Consolidation Materials. The BS-10 series stabilizer is prepared with the main agent of the silicone-modified acrylic resin emulsion and added with an appropriate amount of silica sol solution, and in situ test and laboratory tests on soil samples of Gaochang Ruins were carried out.

The silicone-modified acrylic resin emulsion used for experiments is a transparent aqueous emulsion, with solid content of $31-34 \%$, viscosity of $<1000 \mathrm{cps}$ (Brookfield viscometer $\mathrm{LVF} 1 \sim 3 \# / 60 \mathrm{rpm} / 30^{\circ} \mathrm{C}$ ), $\mathrm{PH}$ value of $7.0-9.0$, and particle size of $0.02 \mathrm{~nm}$, and featuring excellent permeability, sealing, water resistance, and weather resistance. The silica sol consists of $\mathrm{SiO}_{2}$ content of $26.1 \%, \mathrm{NaO}$ content of $0.23 \%, \mathrm{PH}$ 


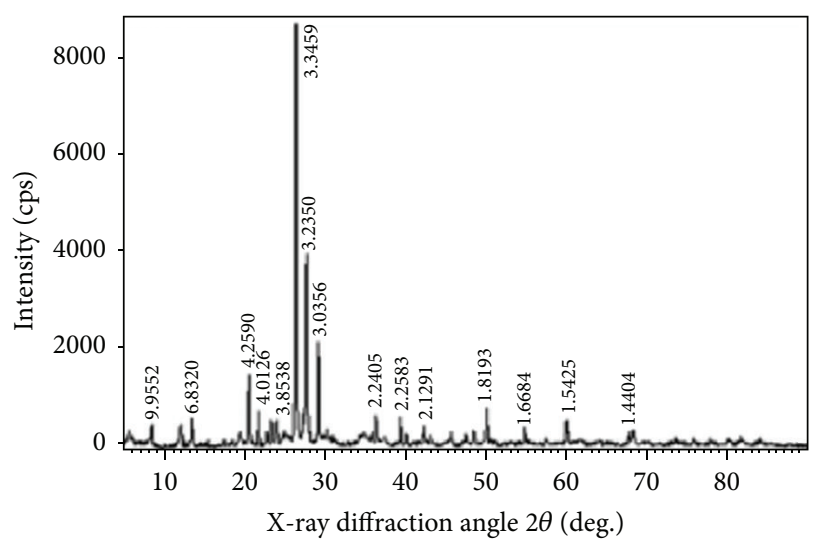

(a) XRD pattern of rammed earth samples

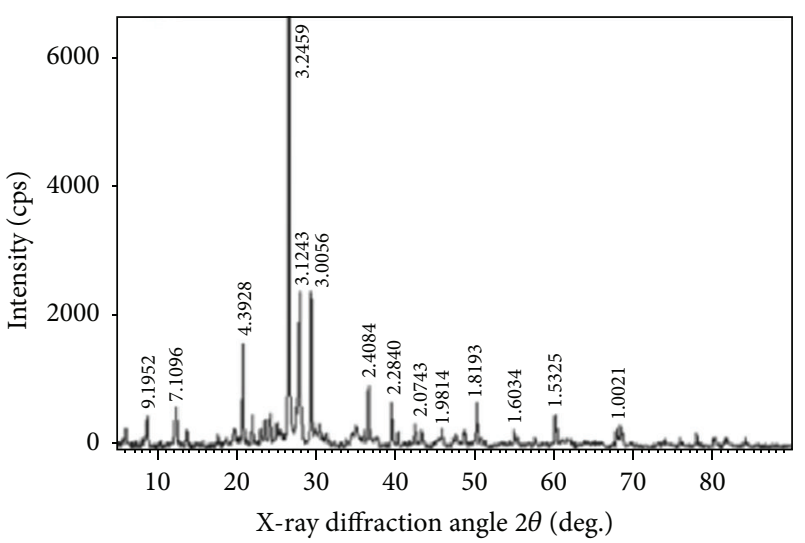

(b) XRD pattern for adobe samples

Figure 2: X-ray diffraction analysis results (test condition: $40 \mathrm{kV}, 35 \mathrm{~mA}$; scan type: continuous; temperature: $25^{\circ} \mathrm{C}$; and anode material: $\mathrm{Cu}$ ).

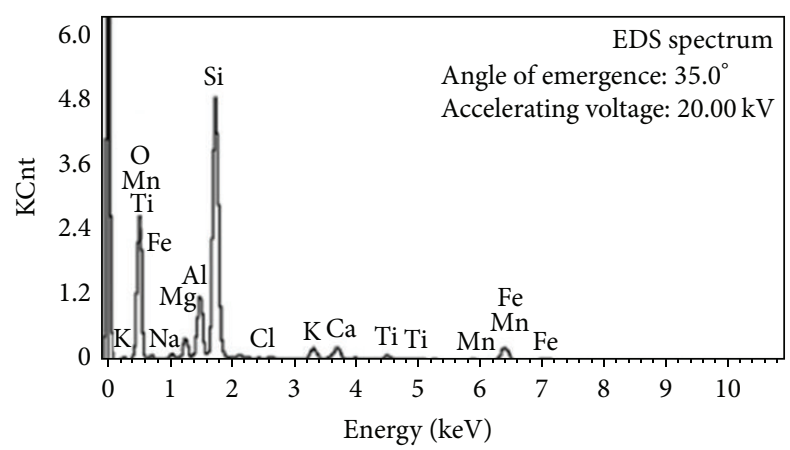

Full-scale 5522 cts cursor: 0.014 (6195cts)

FIGURE 3: EDS analysis results of adobe sample.

value of 9.4, density of $1.167 \mathrm{~g} / \mathrm{cm}^{3}$, and average particle size of $12.6 \mathrm{~nm}$ and features low viscosity, excellent permeability, and larger specific surface area.

3.2. Sample Preparation. With reference to the ASTM codes related to cement-soil and the Chinese soil test procedures [27-29], the wind erosion tests are used with $100 \times 100 \times$ $100 \mathrm{~mm}^{3}$ test cubes, unconfined compressive strength tests are used with cylinder test blocks in diameter of $40 \mathrm{~mm}$ and height of $78 \mathrm{~mm}$, and other tests are used with $50 \times 50 \times$ $50 \mathrm{~mm}^{3}$ test cubes, of which the test cubes or blocks are handmade and in dimensional error of $\pm 2 \mathrm{~mm}$.

Adopt two modified acrylic emulsions of BS-10a and BS$10 \mathrm{~b}$ for testing, prepare with the National Starch products $\mathrm{KD} 8$ and KD26 modified, and use the concentrations of $3 \%, 5 \%, 8 \%$, and $15 \%$, and consolidate the samples using the same spraying technology practically used on projects. The consolidation solution is calculated according to the maximum saturation $S_{r}=85 \%$ [30], and the application rate of consolidation fluid is as follows:

$$
U=\left(1-\frac{\rho_{d}}{G_{s} \rho_{w}}\right) v \times 85 \%,
$$

where $\rho_{d}$ is dry density $\left(\mathrm{g} / \mathrm{cm}^{3}\right)$ of sample; $v$ is total volume of sample $\left(\mathrm{cm}^{3}\right) ; G_{s}$ is relative density of the soil, often taken as $G_{s}=2.70\left(\mathrm{~g} / \mathrm{cm}^{3}\right)$; and $\rho_{w}$ is water density $\left(\mathrm{g} / \mathrm{cm}^{3}\right)$.

The sample numbering is as follows.

$\mathrm{X}-1$ is the sample for undisturbed rammed soil; $\mathrm{X}-2$ is the sample for BS-10a consolidated rammed soil; X-3 is the sample for BS-10b consolidated rammed soil; X-4 is the sample for undisturbed adobe; X-5 is the sample for BS-10a consolidated adobe; $\mathrm{X}-6$ is the sample for BS-10b consolidated adobe.

\section{Consolidation Effect and Discussion}

4.1. Permeability Test. The preservation of the earthen archaeological site follows the basic principles as follows: "after the consolidation of material, the soil still has good permeability, water resistant but not water-repellent $[31,32]$." To verify the bonding force between soil particles, changes in microstructure, and its effect on soil permeability upon consolidation of BS-10 material, the test was used with the TST-55A-type permeameter to determine the changes in soil permeability upon consolidation with modified acrylic emulsions BS-10a and BS-10b.

The test results of the permeability coefficient of various types of soils on the archaeological site are as shown in Table 5.

During test, in 1 minute after the instrument inlet valve is opened, the undisturbed sample of rammed earth and adobe were found steady water outflow from the outlet. Upon consolidation of the BS-10 emulsion, the soil samples were completely water soaked upon $5 \mathrm{~min}$ opening of the inlet valve, and the water flowed out from the outlet after 30 minutes, featuring small amount and rain droplet form.

On the contrary, with the consolidation effect of PS material [31] (the permeability of soil improved; although it can make the soil get sufficient mechanical strength in a relatively short time, the infiltration rate of rainwater was accelerated simultaneously), the test results showed that the permeability of consolidated soil by BS-10 was significantly lower than that of the undisturbed soil, with the permeability 
TABLE 5: Permeability coefficient of soils on the archaeological site.

\begin{tabular}{lcccccc}
\hline Soil type & X-1 & X-2 & X-3 & X-4 & X-5 & X-6 \\
\hline Permeability coefficient $(\mathrm{cm} / \mathrm{s})$ & $1.21 \times 10^{-6}$ & $1.83 \times 10^{-7}$ & $1.89 \times 10^{-7}$ & $1.33 \times 10^{-6}$ & $1.92 \times 10^{-7}$ & $1.96 \times 10^{-7}$ \\
\hline
\end{tabular}

TABLE 6: Unconfined compressive strength statistics.

\begin{tabular}{lcccccc}
\hline Number & X-1 & X-2 & X-3 & X-4 & X-5 & X-6 \\
\hline Mean (KPa) & 1134.43 & 1582.84 & 1157.40 & 1088.18 & 1386.10 & 1743.30 \\
Mean square error & 102.10 & 110.80 & 94.64 & 97.94 & 97.03 & 87.17 \\
Coefficient of variation (\%) & 9 & 7 & 6 & 9 & 7 & 5 \\
\hline
\end{tabular}

coefficient reduced by about 15 times, as well as certain water resistance. At the same time, the consolidated soil immersed in water was relatively easy to permeate, the BS10 materials did not clog the connectivity between soil pores, and the moisture inside and outside the soil could still freely exchange, exhibiting good permeability.

4.2. Ageing Test. The BS-10 (modified acrylic emulsion) belongs to polymer materials, and ageing is inevitable $[33,34]$. The Turpan region where the Gaochang Ruins are located features more sunny days, strong sunlight, and high UV intensity, and ageing is often accompanied by color change to make the site show obvious traces of restoration. At the same time, more attention should be paid to the weakening effect of the material ageing on the cementation among soil particles.

This test was used with UV ageing method and $300 \mathrm{~W}$ high pressure mercury lamp for irradiating the soil of the site. The light source was $20 \mathrm{~mm}$ from the sample surface, with a total of 500 hours for irradiation (exposed in day time with 12 hours and stopping exposure at night). The strength loss of the samples was regularly measured, and the changes in appearance were observed. During test, the soil samples were into the closed fume hood, the high pressure mercury lamp was turned on, and the temperature in the hood reached 65$70^{\circ} \mathrm{C}$ within half an hour.

The results showed that the soil samples had intact appearance and essentially unchanged color. Upon consolidation with the modified acrylic emulsion, the color of the earthen archaeological site was found slightly changed. Compared with undisturbed soil samples, the color difference was in the range of $6 \sim 11$. After UV irradiation for $500 \mathrm{~h}$, the color of the consolidated soil slightly changed compared with the soil before consolidation, with color difference in the range of $0 \sim 6$. The soil color would not have significant color differences compared with the undisturbed soil, which was indiscernible with naked eye, and thus belonged to the acceptable range. In addition, the soil strength showed slight increase over the prolonged ultraviolet irradiation, featuring smaller strength loss against greater concentration; it was similar to the effect of PS consolidation [12]. This indicated that the BS-10 material had good ageing resistance and long service life.

4.3. Unconfined Compressive Strength Test. The unconfined compressive strength is a concentrated expression of the mechanics indicators of soil, which is closely related to the physical and mechanical indexes of consolidated soil, for example, wind erosion resistance, as well as permeability resistance, but also easy to measure [35-37].

This test was permeated and consolidated using dripping method, with consolidation amount as $85 \%$ of the maximum saturation, as well as indoor curing for 1 month before test. The test equipment was selected with YYW-2 strain control type unconfined pressure meter, of which the loading rate was controlled at strain rate of $1 \sim 3 \%$ per minute. When the axial strain $<3 \%$, the readings were taken at interval of $0.5 \%$ (or $0.04 \mathrm{~mm}$ ). When the axial strain $\geq 3 \%$, the readings were taken at interval of $1 \%(0.08 \mathrm{~mm})$. The test results are as shown in Table 6 and Figure 4.

As can be seen, the samples consolidated with BS-10 material were found with improved strength, irrespective of rammed earth or adobe. The compressive strengths of rammed earth samples were increased by 1.395 and 1.391 times, respectively, upon consolidation with BS-10a and BS-10b. The compressive strengths of adobe samples were increased by 1.474 and 1.602 times, respectively, upon consolidation with BS-10a and BS-10b. The stress-strain curve for the rammed earth samples consolidated with BS-10a solution gradually became flat. In addition, the "crusting" phenomenon on the surface of consolidated adobe and rammed earth samples was not found during test, and the failures were all breakups without any obvious signs. After consolidation, the soil surface and the internal parts have good bonding strength.

The two soil samples were found with limited strength increase upon consolidation, which still had room for improvement, and this was the similar defect of PS and $\mathrm{SH}$ material consolidation $[12,16]$. But the consolidated solution of PS has the best concentration and the optimal consolidation times, which can increase the unconfined compressive strength of the consolidated soil sample by 2 times [12]. It will be analyzed in follow-up study.

4.4. Anti-Freeze-Thaw Test. The Turpan region features high humidity and great temperature difference, and the damage effect of freezing and thawing on the archaeological site was particularly significant. Therefore, the studies on anti-freezethaw of soil are also crucial $[38,39]$.

With reference to the meteorological data in 2001 2005 years in Turpan region, and on the basis of its characteristic data (Figure 5), tests were conducted on changing laws by simulating one hour as a month. The test temperatures were 


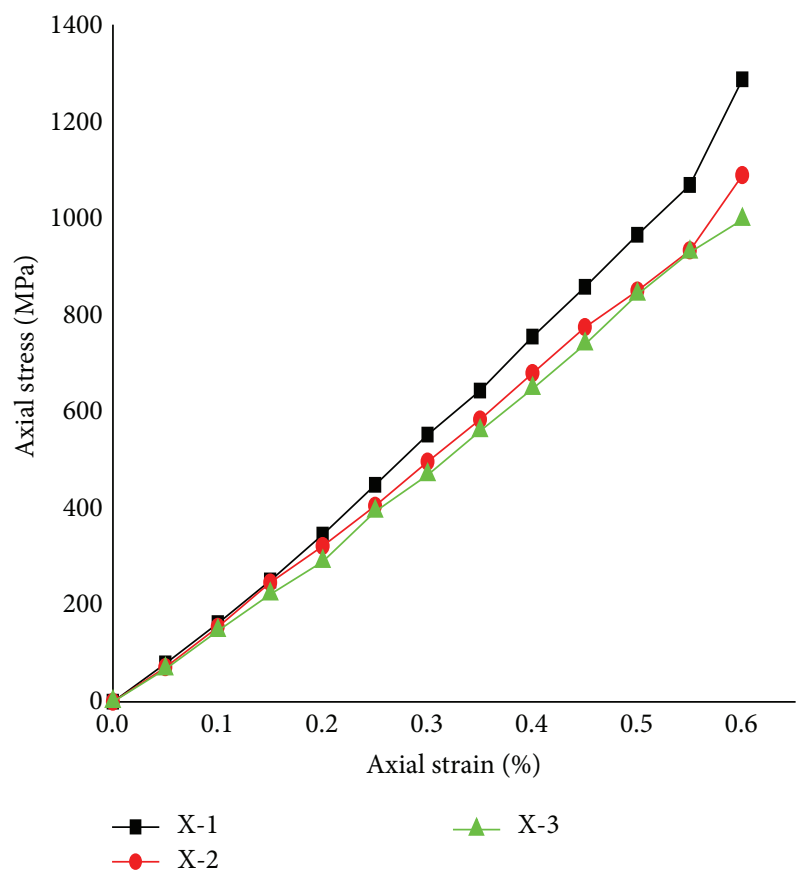

(a) Axial stress-strain curve for rammed earth

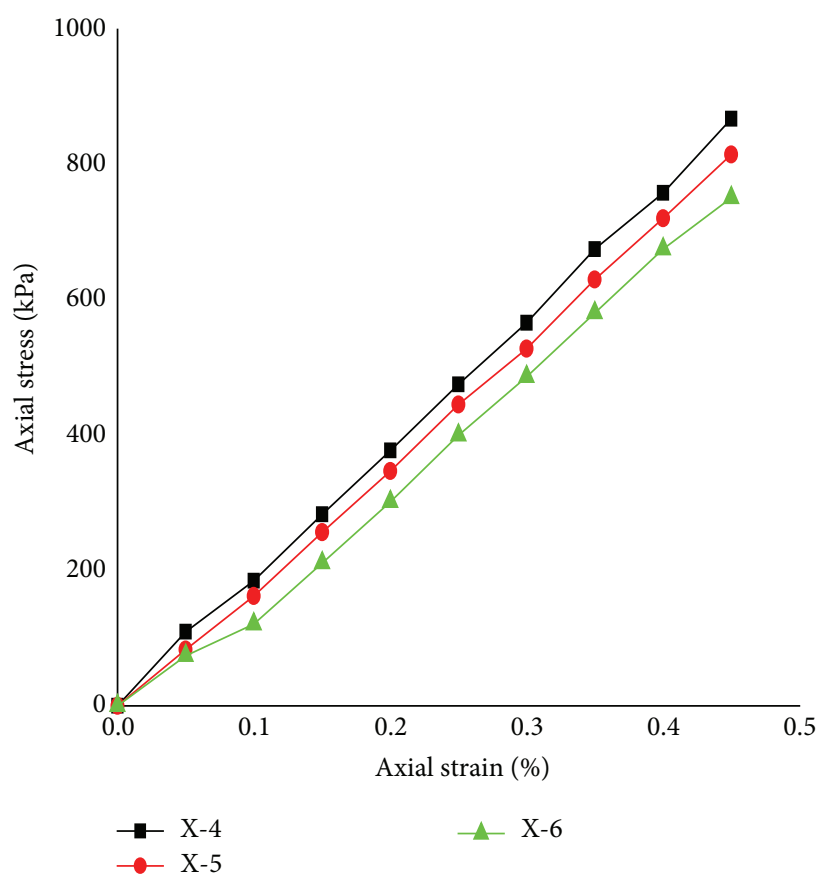

(b) Axial stress-strain curve for adobe

FIGURE 4: Unconfined compressive strength test results.

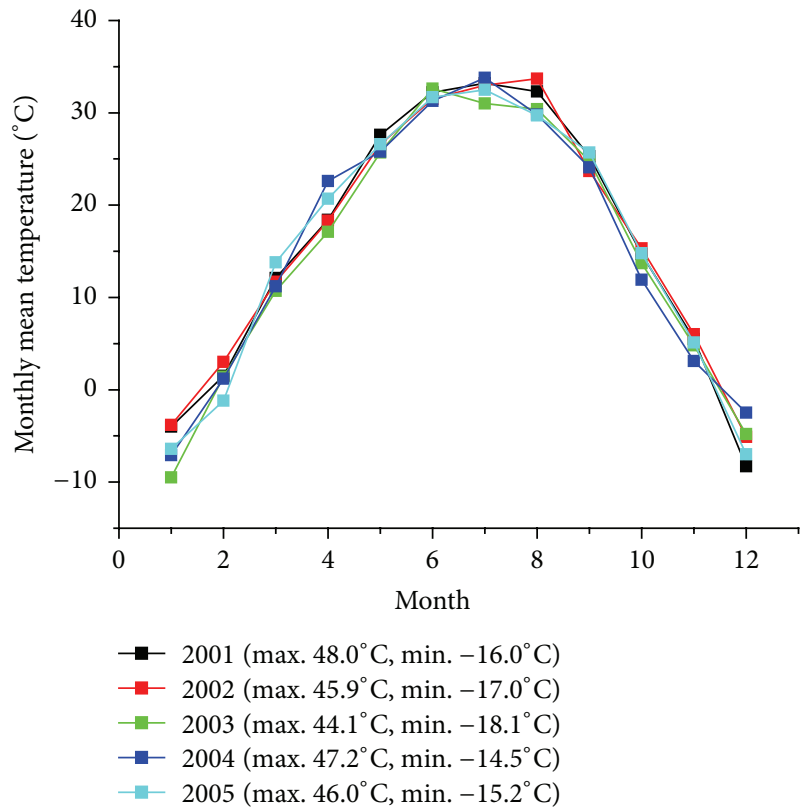

FIgURE 5: Meteorological data in 2001 2005 years in Turpan region.

controlled as continuous change in the range of $-20 \sim 50^{\circ} \mathrm{C}$, and the simulation of the temperature change process of one year was considered to be completed with a freeze-thaw cycle.

The moisture content of consolidation sample was $2 \% \sim 2.5 \%$ (near to the undisturbed soil), took 5 times of freeze-thaw cycles, and then measured the mass loss and its compressive strength after drying. The results showed that the mass loss and strength loss of soil samples in the freeze-thaw cycles were very small, both were under $1 \%$ and had no increase tendency with cycle number of freeze-thaw, and no signs of cracking or other damage appeared on the surface, mainly in that the Turpan region where the sites are located featured scarce rainfall, strong sunlight, and small moisture content in soil, thus insignificant freeze-thaw effect. Therefore, for the arid region in the northwest China, the freeze-thaw is not the main factor causing the destruction of the site.

To further study the influence on the soil moisture under the effect of freeze-thaw, a total of 30 remolded samples in 5 groups were added with water in proportion of $5 \%$, $10 \%, 15 \%$, and $20 \%$, respectively, while one group of water samples not added with water were reserved for comparison. The temperature change process of a quarter was simulated every 4 hours, and a total of two freeze-thaw cycles were conducted. The results showed that, with the increase of moisture content in soil, the chances of soil damage were significantly increased. As the first cycle of high and low temperature had evaporated most of the water in the soil and the permeability coefficient decreased greatly after the consolidation, so, after the second cycle of freeze-thaw, the destruction phenomenon was insignificant, and only few tiny cracks were found on the surface part.

In conclusion, when the moisture content was low, the anti-freeze-thaw ability of the consolidated soil sample was better than that of undisturbed soil, but there was no such similar phenomenon shown after SH consolidation that the compressive strength increased first and then decreased with the number of freeze-thaw cycles [40]. 
4.5. Wind Erosion Test. In the northwest China, the sanddriving heavy winds eroded these precious cultural relics sites almost every year at an alarming rate, resulting in severe undercutting of the bottom of the archaeological sites [41]. So the wind erosion resistance of soil is the critical factor that should be taken into consideration in the archaeological sites consolidation [42-44].

This test is based on the wind speed data of Turpan region in 2001 2005 years (Figure 6). The test tunnel is type of opencircuit closed wind tunnel, with tunnel length of $37.78 \mathrm{~m}$, sectional area of $0.6 \times 1 \mathrm{~m}$, test section length $16.23 \mathrm{~m}$, and 1 degree of lifting angle to eliminate the axial acceleration. The wind speed is continuously adjustable in the range of $1 \sim 40 \mathrm{~m} / \mathrm{s}$, and the turbulence intensity is below $0.4 \%$.

Before the experiment, the soil samples were weighed and horizontally placed, and the sample placing sequence was changed with the wind speed to avoid the fact that the windward side area of soil sample was decreased by the sand accumulation. Firstly, $30 \mathrm{~m} / \mathrm{s}$ non-sand-driving wind was used to deflate the samples for $4 \mathrm{~min}$, and then sanddriving winds were used to deflate the samples continuously at rates of $7 \mathrm{~m} / \mathrm{s}, 10 \mathrm{~m} / \mathrm{s}, 12 \mathrm{~m} / \mathrm{s}, 15 \mathrm{~m} / \mathrm{s}, 20 \mathrm{~m} / \mathrm{s}, 25 \mathrm{~m} / \mathrm{s}$, and $30 \mathrm{~m} / \mathrm{s}$, respectively [45]. The wind erosion rates before and after the consolidation were shown in Table 7 (the wind erosion amount was obtained by weighting the covered soil by removal from the surface after experiment).

As can be seen from Table 7 and Figure 7, the effect of wind erosion on soil was very limited, and the soil samples were mainly subject to shear stress of wind. Under the sanddriving wind effect, wind erosion amount was related to the soil surface strength and was in direct proportion with wind speed. The soil samples were influenced by the impact of the sands in the wind and the shear effect generated by the rotation of the sand; the soil whose surface was consolidated was destroyed making the undisturbed soil which is vulnerable to be eroded exposed and they were cracked by the shock of solid particles produced by sanddriving wind. So the wind erosion rate of sand-driving wind was much greater than that of non-sand-driving wind.

The erosion moduli of soil samples consolidated with BS-10a and BS-10b are roughly equal. But, compared with the unconsolidated samples, their erosion resistance was substantially improved. Under deflation of sand-driving wind at low speed of below $15 \mathrm{~m} / \mathrm{s}$, the wind erosion moduli for the samples were decreased by 5 6 times, and the erosion amount slightly rose with the increase in wind speed; under deflation of sand-driving wind at speed of above $15 \mathrm{~m} / \mathrm{s}$, the mass loss of undisturbed soil samples grew exponentially, and the mass loss of the consolidated sample substantially increased compared with the low speed segment of wind. After consolidation, the erosion resistance of soil sample was significantly enhanced, and the wind erosion modulus was decreased by 7 8 times.

Based on Table 7 and Figure 7, we fitted the relation between wind speed and wind erosion modulus of undisturbed rammed soil and BS-10 consolidated soil as follows:

$$
1.20^{(X-a)}=V,
$$

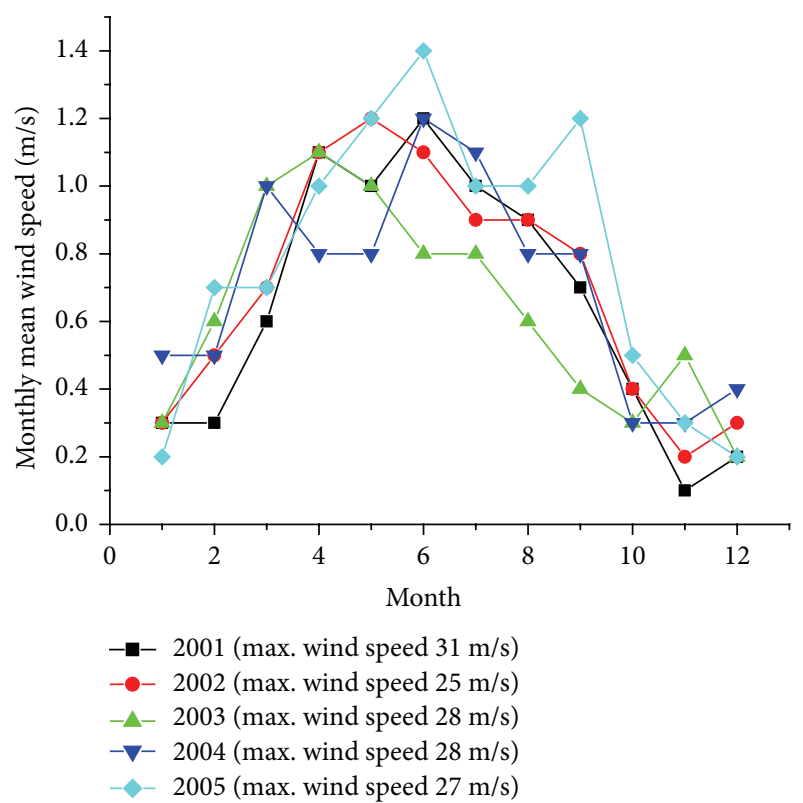

FIGURE 6: Wind speed data in 2001 2005 years in Turpan region.

where $X$ is wind speed $(\mathrm{m} / \mathrm{s}) ; V$ is wind erosion modulus $\left(\mathrm{Kg} \cdot \mathrm{m}^{-2} \cdot \mathrm{h}^{-1}\right)$; and $a$ is the relation coefficient between wind speed and wind erosion modulus, in undisturbed rammed soil: $a=16.0$, in BS-10a consolidated rammed soil: $a=$ 24.9 , and in BS-10b consolidated rammed soil $a=24.7$. The relation between wind speed and wind erosion modulus of undisturbed adobe and BS-10 consolidated adobe is similar to that of rammed soil.

Set up the wind function in windy days according to Figure 6, which obeys the normal distribution $X \sim N$ (9.5, 23.8), for BS-10a consolidated rammed soil:

$$
M=\int_{7}^{30} 1.2^{(X-a)} \cdot T \cdot \frac{1}{\sigma \sqrt{2 \pi}} \cdot e^{(x-\mu)^{2} / 2 \sigma^{2}} d x
$$

where $M$ is the wind erosion modulus $\left(\mathrm{Kg} \cdot \mathrm{m}^{-2} \cdot \mathrm{h}^{-1}\right)$ and $T$ is the duration time of deflation (h).

Integrating formula (3), $M=0.18 T$ can be obtained, and Table 8 can be obtained similarly.

It can be seen from Table 8 that the consolidation effect of BS-10a was a little better than that of BS-10b in the natural wind erosion in Turpan; the wind erosion moduli of undisturbed rammed earth and adobe were reduced by 5 times and 7 times relatively. And the consolidation effect of abode was relatively good mainly because the erosion debris content in the abode surface was relatively high, so the consolidation material can penetrate more fully into the soil. Though the BS-10 consolidation material is difficult in achieving the wind erosion resistance by 6 to 24 times as the PS consolidation material [12], it can also satisfy the requirement of wind erosion resistance in arid region as the windy days in Turpan are not so frequent and the average wind speed is less than $1 \mathrm{~m} / \mathrm{s}$. 
TABLE 7: Comparison of wind erosion amount before and after the consolidation.

\begin{tabular}{|c|c|c|c|c|c|c|}
\hline Sample type & Sample size $\left(\mathrm{cm}^{2}\right)$ & $\begin{array}{l}\text { Deflation time } \\
\quad(\min )\end{array}$ & $\begin{array}{l}\text { Wind speed } \\
\qquad(\mathrm{m} / \mathrm{s})\end{array}$ & $\begin{array}{l}\text { Deflation rate } \\
\quad(\mathrm{g})\end{array}$ & $\begin{array}{c}\text { Wind erosion } \\
\text { modulus } \\
\left(\mathrm{Kg} \cdot \mathrm{m}^{-2} \cdot \mathrm{h}^{-1}\right)\end{array}$ & Remark \\
\hline \multirow{8}{*}{$\begin{array}{l}\text { Sample for undisturbed } \\
\text { rammed soil }\end{array}$} & \multirow{8}{*}{$10 \times 10$} & 4 & 30 & 0.00 & 0.00 & Non-sand-driving wind \\
\hline & & 20 & 7 & 0.31 & 0.093 & \multirow{7}{*}{ Sand-driving winds } \\
\hline & & 20 & 10 & 0.47 & 0.141 & \\
\hline & & 20 & 12 & 1.29 & 0.387 & \\
\hline & & 10 & 15 & 0.54 & 0.324 & \\
\hline & & 10 & 20 & 3.68 & 2.208 & \\
\hline & & 4 & 25 & 4.48 & 6.720 & \\
\hline & & 4 & 30 & 6.07 & 9.105 & \\
\hline \multirow{8}{*}{$\begin{array}{l}\text { Sample for BS-10a } \\
\text { consolidated rammed soil }\end{array}$} & \multirow{8}{*}{$10 \times 10$} & 4 & 30 & 0.00 & 0.00 & \multirow[t]{3}{*}{ Non-sand-driving wind } \\
\hline & & 20 & 7 & 0.06 & 0.018 & \\
\hline & & 20 & 10 & 0.10 & 0.030 & \\
\hline & & 20 & 12 & 0.33 & 0.099 & \multirow{5}{*}{ Sand-driving winds } \\
\hline & & 10 & 15 & 0.11 & 0.066 & \\
\hline & & 10 & 20 & 0.65 & 0.390 & \\
\hline & & 4 & 25 & 0.75 & 1.125 & \\
\hline & & 4 & 30 & 1.50 & 2.250 & \\
\hline \multirow{8}{*}{$\begin{array}{l}\text { Sample for BS-10b } \\
\text { consolidated rammed soil }\end{array}$} & \multirow{8}{*}{$10 \times 10$} & 4 & 30 & 0.00 & 0.00 & \multirow[t]{8}{*}{ Non-sand-driving wind } \\
\hline & & 20 & 7 & 0.05 & 0.015 & \\
\hline & & 20 & 10 & 0.06 & 0.018 & \\
\hline & & 20 & 12 & 0.12 & 0.036 & \\
\hline & & 10 & 15 & 0.14 & 0.084 & \\
\hline & & 10 & 20 & 0.79 & 0.474 & \\
\hline & & 4 & 25 & 0.95 & 1.425 & \\
\hline & & 4 & 30 & 1.44 & 2.160 & \\
\hline \multirow{8}{*}{$\begin{array}{l}\text { Sample for undisturbed } \\
\text { adobe }\end{array}$} & \multirow{8}{*}{$10 \times 10$} & 4 & 30 & 0.00 & 0.00 & \multirow[t]{8}{*}{ Non-sand-driving wind } \\
\hline & & 20 & 7 & 0.30 & 0.090 & \\
\hline & & 20 & 10 & 1.09 & 0.327 & \\
\hline & & 20 & 12 & 1.08 & 0.324 & \\
\hline & & 10 & 15 & 2.30 & 1.380 & \\
\hline & & 10 & 20 & 5.48 & 3.228 & \\
\hline & & 4 & 25 & 11.52 & 17.28 & \\
\hline & & 4 & 30 & 13.97 & 20.96 & \\
\hline \multirow{8}{*}{$\begin{array}{l}\text { Sample for BS-10a } \\
\text { consolidated adobe }\end{array}$} & \multirow{8}{*}{$10 \times 10$} & 4 & 30 & 0.00 & 0.00 & \multirow[t]{8}{*}{ Non-sand-driving wind } \\
\hline & & 20 & 7 & 0.03 & 0.009 & \\
\hline & & 20 & 10 & 0.11 & 0.033 & \\
\hline & & 20 & 12 & 0.15 & 0.045 & \\
\hline & & 10 & 15 & 0.45 & 0.270 & \\
\hline & & 10 & 20 & 1.00 & 0.600 & \\
\hline & & 4 & 25 & 1.83 & 2.745 & \\
\hline & & 4 & 30 & 2.05 & 3.075 & \\
\hline \multirow{8}{*}{$\begin{array}{l}\text { Sample for BS-10b } \\
\text { consolidated adobe }\end{array}$} & \multirow{8}{*}{$10 \times 10$} & 4 & 30 & 0.00 & 0.00 & \multirow[t]{8}{*}{ Non-sand-driving wind } \\
\hline & & 20 & 7 & 0.05 & 0.015 & \\
\hline & & 20 & 10 & 0.25 & 0.075 & \\
\hline & & 20 & 12 & 0.17 & 0.051 & \\
\hline & & 10 & 15 & 0.35 & 0.210 & \\
\hline & & 10 & 20 & 1.08 & 0.648 & \\
\hline & & 4 & 25 & 1.70 & 2.550 & \\
\hline & & 4 & 30 & 2.16 & 3.240 & \\
\hline
\end{tabular}


TABLE 8: Wind erosion amount of soil samples before and after BS-10 consolidation in the natural wind erosion in Turpan.

\begin{tabular}{lccccc}
\hline Undisturbed rammed soil & BS-10a & BS-10b & Undisturbed adobe & BS-10a & BS-10b \\
\hline $0.93 T$ & $0.18 T$ & $0.19 T$ & $1.46 T$ & $0.19 T$ & $0.21 T$ \\
Decreased times & 5.2 & 4.9 & Decreased times & 7.7 & 7.0 \\
\hline
\end{tabular}

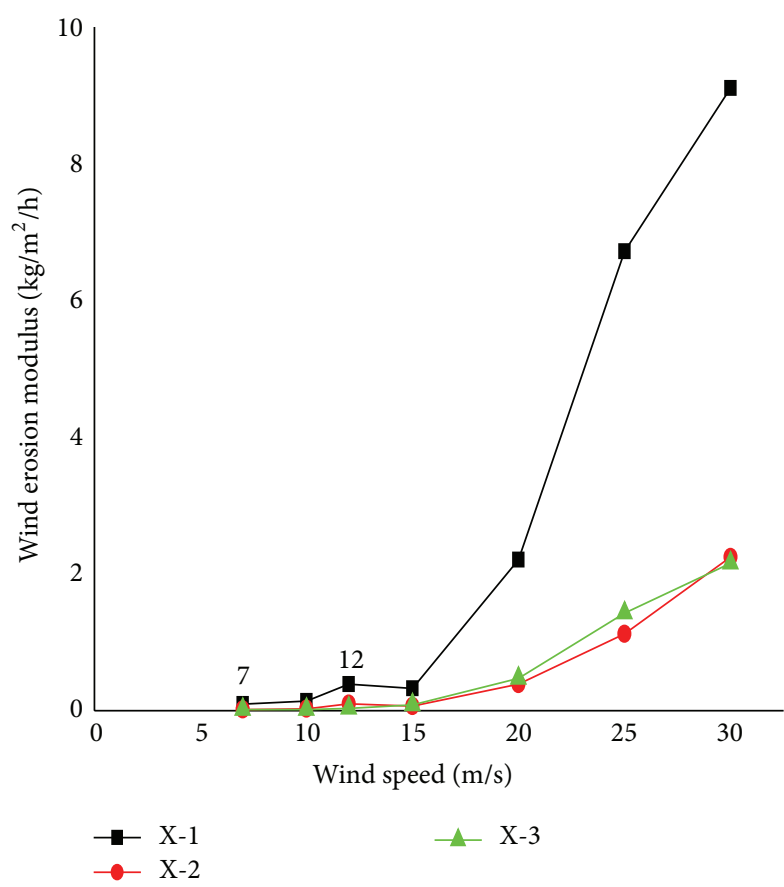

(a) Wind speed versus wind erosion modulus curve for rammed earth

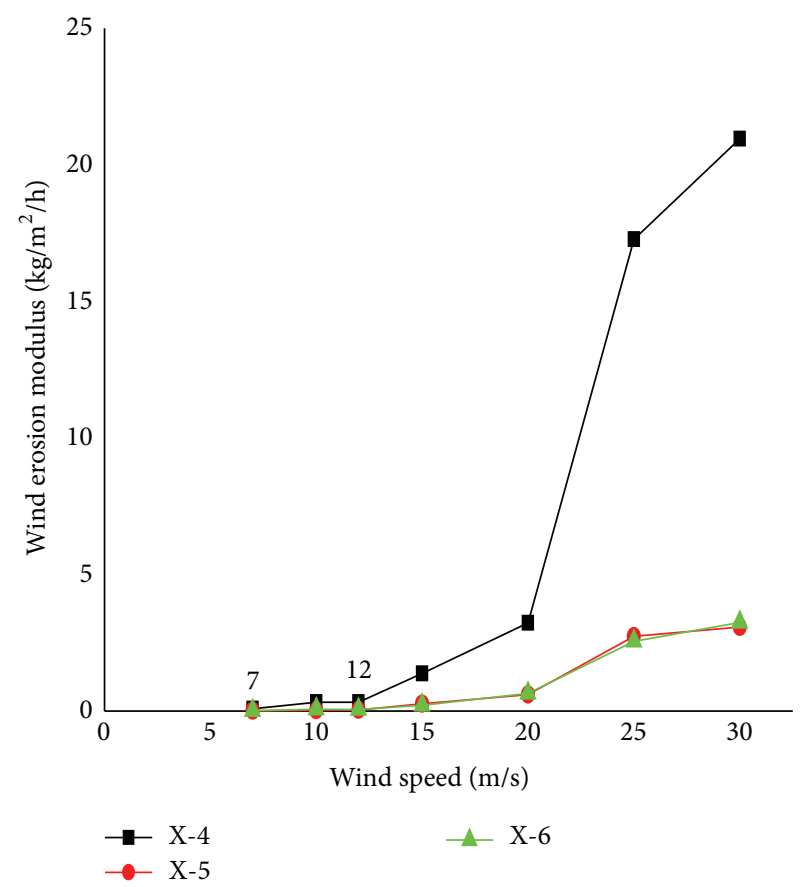

(b) Wind speed versus wind erosion modulus curve for adobe

FIGURE 7: Wind speed versus wind erosion modulus curve.

4.6. Scanning Electron Microscopy (SEM) Analysis. The factors influencing weathering of the earthen archaeological sites include internal factor and external factor. The internal factors are the composition and the nature of the earthen archaeological site itself, including soil composition and microstructure [46]. The external factors refer to the influence from external environmental factors, including temperature, humidity, and moisture content. The consolidation of earthen archaeological sites was generally considered as changing the particle structure from the soil internal parts, thereby increasing the binding force between soil particles.

This microstructure analysis test on soil was conducted using AMRAY100-B scanning electron microscope for scanning analysis on the soil samples with electron microscope [47]. The SEM analysis results of soil samples at magnification factor of 1,000 are as shown in Figure 8.

This paper selected the scanning results of more representative BS-10b for analysis, of which the analysis results of BS-10a were found similar.

As can be seen from Figures 8(a) and 8(d), the undisturbed soil surfaces were formed by pile-up of soil particles in varying sizes, and the particle sizes are distributed between 2 20 microns and mostly concentrated in the 2 10 microns. The particles are arranged disorderly, with varying sizes distributed alternately, surface undulated significantly, and particle pores in varying sizes. Irrespective of surface or internal parts of the soil structure, the undisturbed soil structure is relatively loose and has large pores; the soil particles are in smaller scaly shape, having only the geometric accumulation of primary minerals, and free of other firm connections.

As can be seen from Figures 8(b), 8(c), 8(e), and 8(f), compared with the undisturbed soil samples, the consolidated soil surfaces feature dense grain structure and compact accumulation of mineral; the soil particles are cemented as a whole; the whole volume of pores decreased but average diameters of single pore increased, because the soil particles were gathered, and the BS consolidation material was cemented and filling some pores. The soil has relatively more flocculent colloids, small particles are embedded in the colloid to form into large particles, and large particles are alternatively connected to form into the soil skeleton; the gelatinous substances are distributed throughout the sample, and relatively more pores exist between skeletons, most of which are large pores.

Therefore, the BS-10 material and the soil have good compatibility and can change the separated and clay particle microstructure to form into dense grid gel structure and significantly improve the loose nature of the soil; this mainly benefited from the epoxide group property of high reactivity 


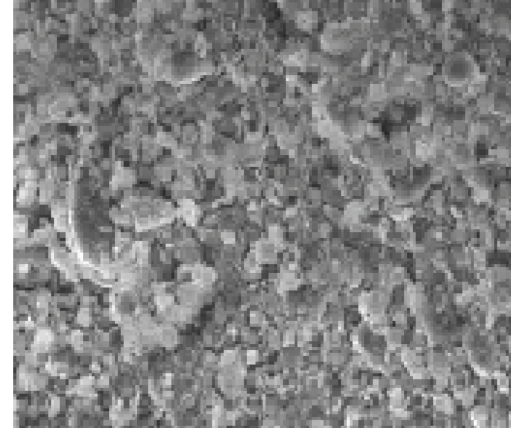

(a) Undisturbed rammed earth surface

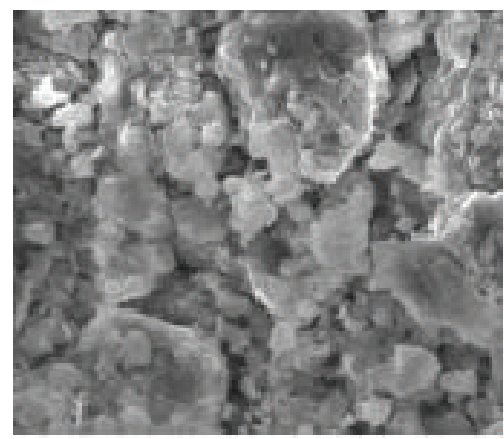

(d) Undisturbed adobe surface

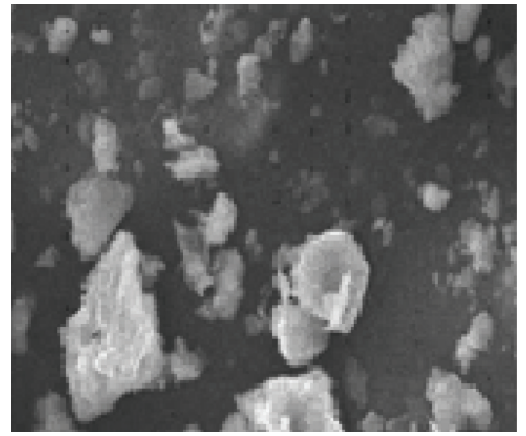

(b) Rammed earth surface after consolidation with BS-10b

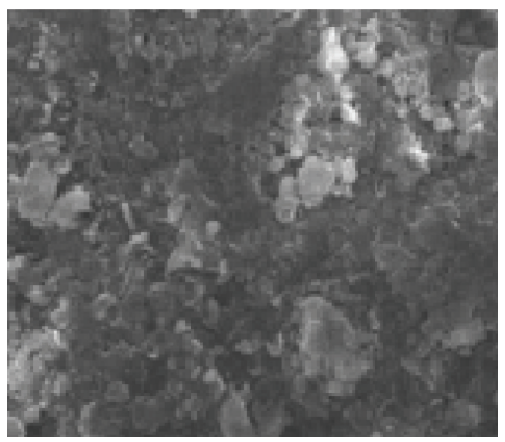

(e) Adobe surface after consolidation with BS-10b

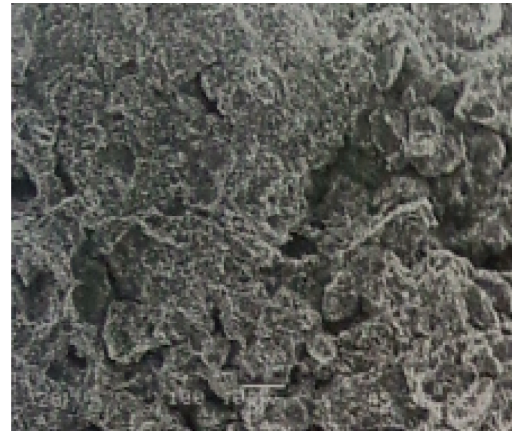

(c) Rammed earth internal parts after consolidation with BS-10b

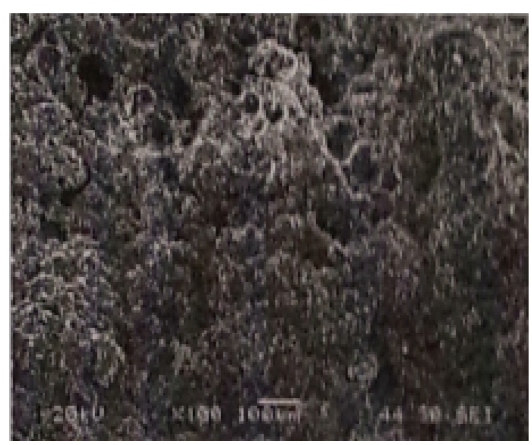

(f) Adobe internal parts after consolidation with BS-10b

FIGURE 8: SEM analysis results.

and cohesiveness, as well as the good compatibility between inorganic $\mathrm{SiO}_{2}$ network and the soil, which is also the basic property of most consolidation materials [12, 16, 47]. This dense grid gel structure qualified the consolidated soil with good water resistance and stability.

4.7. Water Resistance Test. The soils in the earthen archaeological sites feature easy disintegration when exposed to water and are prone to disintegration and collapse under the effect of rain and groundwater, thereby affecting the stability of the earthen archaeological sites.

The experiment was done indoors in $25^{\circ} \mathrm{C}$, immerse the soil samples in a glass container, flood the soil completely with water, and study the water resistance and stability of soil under hydrostatic pressure [48]. The destruction processes of samples in the water are experimentally observed and recorded, and the wetting speed and the disintegration state are tested. The test results are as shown in Table 9.

During the experiment, it was found that, after immersion of the undisturbed soil samples of the rammed soil, the surface was observed as immediate residues were falling and peeling, the corners were quickly collapsed, and the soil samples were completely disintegrated in around $40 \mathrm{~s}$; the soil consolidated with BS-10 solution had significantly improved water resistance, without immediate damage to the surface immediately upon exposure to the water, and the surface produced bubbles gradually; the residues started to fall off from the soil surface in 30 90 min, the four corners were partially collapsed within $1 \sim 2 \mathrm{~h}$, and the samples were completely disintegrated within $3 \sim 5 \mathrm{~h}$; the destruction rate of the samples with worm hole was faster. This phenomenon is mainly because the water penetrated into the pores with different speed, making the expansion rate of diffusion layer uneven, as a result, the repulsive force among the soil particles exceeded the attractive force to produce stress concentration, and the soil collapsed along the place where the repulsive force exceeded the attractive force most. It also should be noted that the number of dry-wet cycles has obvious influence on the water resistance of soil [12]. The changes in immersion state before and after consolidation of adobe were similar to those of the rammed earth.

The results showed that the water resistance property of consolidated soil sample by BS-10 was increased more obviously than that consolidated by SH (increased by $42.63 \%$ ) [49] but in the end still was completely disintegrated and destructed. The existence of wormholes enabled rapid penetration of water deep into the soil, accelerating the disintegration of the soil. Taking into account the perennial dryness and lack of rain in Turpan region, the soil cannot be completely soaked by rain under normal circumstances; therefore, it can be considered that the BS-10 material can meet the soil consolidation requirements for the soil water resistance in the arid region in northwest China, but the wormhole should be subject to closed treatment before consolidation. 
TABLE 9: Water resistance test results of soil on the archaeological sites of Gaochang Ruins.

\begin{tabular}{|c|c|c|}
\hline Soil type & Sample number & Flooding and disintegration situations \\
\hline \multirow{2}{*}{$\begin{array}{l}\text { Undisturbed } \\
\text { soil of rammed } \\
\text { earth }\end{array}$} & F-1-1 & $\begin{array}{l}\text { The soil residues come off from the surface immediately upon exposure to the water, } \\
\text { and the soil is collapsed completely within } 40 \mathrm{~s}\end{array}$ \\
\hline & F-1-2 & $\begin{array}{l}\text { The soil residues come off from the surface immediately upon exposure to the water, } \\
\text { and the soil is collapsed completely within } 34 \mathrm{~s}\end{array}$ \\
\hline \multirow{2}{*}{$\begin{array}{l}\text { BS-10a } \\
\text { consolidated } \\
\text { rammed earth } \\
\text { sample }\end{array}$} & F-2-1 & $\begin{array}{l}\text { The surface shows bubbles immediately upon exposure to the water, the soil residues } \\
\text { come off in } 30 \mathrm{~min} \text {, and the four corners are locally collapsed in } 1 \mathrm{~h} \text {, and the soil is } \\
\text { collapsed completely within } 3 \mathrm{~h}\end{array}$ \\
\hline & F-2-2 & $\begin{array}{l}\text { The surface shows bubbles immediately upon exposure to the water, the soil residues } \\
\text { come off in } 50 \mathrm{~min} \text {, and the four corners are locally collapsed in } 2 \mathrm{~h} \text {, and the soil is } \\
\text { collapsed completely within } 5 \mathrm{~h}\end{array}$ \\
\hline \multirow{2}{*}{$\begin{array}{l}\text { BS-10b } \\
\text { consolidated } \\
\text { rammed earth } \\
\text { sample }\end{array}$} & F-3-1 & $\begin{array}{l}\text { The surface shows bubbles immediately upon exposure to the water, the soil residues } \\
\text { come off in } 90 \text { min, and the four corners are locally collapsed in } 2 \mathrm{~h} \text {, and the soil is } \\
\text { collapsed completely within } 4 \mathrm{~h}\end{array}$ \\
\hline & F-3-2 (surface with worm hole) & $\begin{array}{l}\text { The surface shows large amount of bubbles immediately upon exposure to the water, } \\
\text { soil residues come off in } 60 \mathrm{~min} \text {, the four corners are locally collapsed in } 1.5 \mathrm{~h} \text {, and the } \\
\text { soil is collapsed completely within } 2 \mathrm{~h}\end{array}$ \\
\hline \multirow{2}{*}{$\begin{array}{l}\text { Undisturbed } \\
\text { soil of adobe }\end{array}$} & F-4-1 & $\begin{array}{l}\text { The soil residues come off from the surface immediately upon exposure to the water, } \\
\text { and the soil is collapsed completely within } 70 \mathrm{~s}\end{array}$ \\
\hline & F-4-2 & $\begin{array}{l}\text { The soil residues come off from the surface immediately upon exposure to the water, } \\
\text { and the soil is collapsed completely within } 80 \mathrm{~s}\end{array}$ \\
\hline \multirow{2}{*}{$\begin{array}{l}\text { BS-10a } \\
\text { consolidated } \\
\text { adobe sample }\end{array}$} & F-5-1 (surface with worm hole) & $\begin{array}{l}\text { The surface shows bubbles immediately upon exposure to the water, soil residues come } \\
\text { off in } 60 \mathrm{~min} \text {, the mud and straw fallen off from the adobe float in the water, the four } \\
\text { corners are locally collapsed in } 2 \mathrm{~h} \text {, and the soil is collapsed completely within } 3 \mathrm{~h}\end{array}$ \\
\hline & F-5-2 & $\begin{array}{l}\text { The surface shows bubbles immediately upon exposure to the water, soil residues come } \\
\text { off in } 80 \mathrm{~min} \text {, the mud and straw fallen off from the adobe float in the water, the four } \\
\text { corners are locally collapsed in } 3 \mathrm{~h} \text {, and the soil is collapsed completely within } 4 \mathrm{~h}\end{array}$ \\
\hline \multirow{2}{*}{$\begin{array}{l}\text { BS-10b } \\
\text { consolidated } \\
\text { adobe sample }\end{array}$} & F-6-1 & $\begin{array}{l}\text { The surface shows bubbles immediately upon exposure to the water, soil residues come } \\
\text { off in } 70 \mathrm{~min} \text {, the mud and straw fallen off from the adobe float in the water, the four } \\
\text { corners are locally collapsed in } 2 \mathrm{~h} \text {, and the soil is collapsed completely within } 3 \mathrm{~h}\end{array}$ \\
\hline & F-6-2 & $\begin{array}{l}\text { The surface shows bubbles immediately upon exposure to the water, soil residues come } \\
\text { off in } 65 \mathrm{~min} \text {, the mud and straw fallen off from the adobe float in the water, the four } \\
\text { corners are locally collapsed in } 2.5 \mathrm{~h} \text {, and the soil is collapsed completely within } 3.5 \mathrm{~h}\end{array}$ \\
\hline
\end{tabular}

\section{Conclusion}

This paper gave analysis on the soil characteristics in the archaeological sites of Gaochang Ruins. On such basis, the applicability of the BS-10 series materials in consolidation of the earthen archaeological sites was conducted with experimental study. The results showed that the two materials of BS-10a and BS-10b had similar consolidation properties and desirable consolidation effect on the earthen archaeological sites in arid regions.

After consolidation, the wind erosion resistance of the soil was substantially increased, and the high-speed sanddriving wind caused great harm to the archaeological sites; the soil had excellent ageing resistance; and the soil hydrolysis resistance and stability were also improved.

The unconfined compressive strength is improved in limited range and still has room for improvement.

The freeze-thaw resistance of the dry soil undergoes little change, which is closely related to the soil moisture content. After consolidation, the soil permeation coefficient is reduced, and the moisture content is difficult to permeate, which prevents the freeze-thaw destruction to the soil to certain extent and meets the requirements for consolidation of archaeological sites in arid regions.

The electron microscopy scanning and permeability tests showed that, upon consolidation, the soil featured dense structure, overall cementation, and permeability coefficient reduced by one order of magnitude. However, upon consolidation, the moisture exchange between inside and outside the soil could still be ensured.

These experimental studies were conducted on the consolidation applicability of the BS-10 material on the earthen archaeological sites in arid regions, and the effects of wind erosion and water penetration are the main factors taken into consideration. No matter what kind the soil is, the consolidation material must be compatible with the soil and the soil after consolidation should have good durability; meanwhile, the emphasis points of consolidation are different in different climate condition such as the following: in the humid and rainy region, the water resistance property and stability of the earthen sites after consolidation should be the main factors to be considered; for the coastal region (where it is easy to be eroded by wind), the resistance to acid and salt should be considered first. 


\section{Competing Interests}

The authors declare that there is no conflict of interests regarding the publication of this paper.

\section{References}

[1] E. Fodde, "Traditional earthen building techniques in central Asia," International Journal of Architectural Heritage, vol. 3, no. 2, pp. 145-168, 2009.

[2] A. A. Charnov, "100 years of site maintenance and repair: conservation of earthen archaeological sites in the American Southwest," Journal of Architectural Conservation, vol. 17, no. 2, pp. 59-75, 2011.

[3] E. Fodde, "Structural faults in earthen archaeological sites in central Asia: analysis and repair methods," in Proceedings of the 6th International Conference on Structural Analysis of Historic Construction, D. F. D’Ayala and E. Fodde, Eds., pp. 1415-1422, Taylor \& Francis, Bath, UK, July 2008.

[4] A. R. Gallardo and J. M. L. Osorio, "Historical rammedearth structures in Eastern Andalusia: (Spain) the restoration philosophy of the architect Prieto-Moreno," in Proceedings of the 1st International Conference on Rammed Earth Conservation, pp. 407-412, Valencia, Spain, June 2012 (Spanish).

[5] P. A. Jaquin, C. E. Augarde, and C. M. Gerrard, "Chronological description of the spatial development of rammed earth techniques," International Journal of Architectural Heritage: Conservation, Analysis, and Restoration, vol. 2, no. 4, pp. 377400, 2008.

[6] F. Pacheco-Torgal and S. Jalali, "Earth construction: lessons from the past for future eco-efficient construction," Construction and Building Materials, vol. 29, pp. 512-519, 2012.

[7] Y. Fujii, E. Fodde, K. Watanabe, and K. Murakami, "Digital photogrammetry for the documentation of structural damage in earthen archaeological sites: the case of Ajina Tepa, Tajikistan," Engineering Geology, vol. 105, no. 1-2, pp. 124-133, 2009.

[8] E. Fodde, K. Watanabe, and Y. Fujii, "Preservation of earthen sites in remote areas: the Buddhist monastery of Ajina Tepa, Tajikistan," Conservation and Management of Archaeological Sites, vol. 9, no. 4, pp. 194-218, 2007.

[9] H. Y. Zhao, Z. X. Li, W. F. Han, X. D. Wang, and W. W. Chen, "Main diseases and their causes of earthen ruins in arid region of Northwestern China," Chinese Journal of Rock Mechanics and Engineering, vol. 22, no. 2, pp. 2875-2880, 2003 (Chinese).

[10] P. Jaquin, "Study of historic rammed earth structures in Spain and India," Structural Engineer, vol. 86, no. 2, pp. 26-32, 2008.

[11] T. Wan and J.-H. Lin, "A new inorganic-organic hybrid material as consolidation material for Jinsha archaeological site of Chengdu," Journal of Central South University, vol. 21, no. 2, pp. 487-492, 2014 (Chinese).

[12] F.-G. He, W.-W. Chen, H.-Y. Zhao, M.-L. Sun, and J.-K. Zhang, "Experimental research of PS reinforcing earthen architecture," Journal of Central South University (Science and Technology), vol. 41, no. 3, pp. 1132-1138, 2010 (Chinese).

[13] L. J. Sun, Y. T. Qu, C. C. Zhao, L. L. Wang, and W. Zhang, "Study on surface weather-resistant protective material of applied on the Yangguan Zhai Archaeological Site," Journal of Northwest University (Nature Science Edition), vol. 42, no. 3, pp. 477-482, 2012 (Chinese).

[14] H.-Y. Zhao, X.-D. Wang, Z.-X. Li et al., "Impact of modulus and concentration of potassium silicate material on consolidating earthen architecture sites in arid region," Chinese Journal of Rock Mechanics and Engineering, vol. 25, no. 3, pp. 557-562, 2006 (Chinese).

[15] S. L. Zhou, S. X. Yuan, X. W. Yang, B. F. Guo, and Y. Xia, “Comparison of consolidation effectiveness of acrylic non-aqueous dispersion and other anti-weathering consolidants for earthen architectures and monuments," Sciences of Conservation and Archaeology, vol. 15, no. 2, pp. 40-48, 2003 (Chinese).

[16] Y. M. Wang, Z. C. Yang, and W. W. Chen, "Strength characteristics and mechanism of loess solidified with new polymer materialsh," Chinese Journal of Rock Mechanics and Engineering, vol. 24, no. 14, pp. 2554-2559, 2005 (Chinese).

[17] M. Emiroğlu, A. Yalama, and Y. Erdoğdu, "Performance of ready-mixed clay plasters produced with different clay/sand ratios," Applied Clay Science, vol. 115, pp. 221-229, 2015.

[18] Q.-B. Bui, J.-C. Morel, S. Hans, and P. Walker, "Effect of moisture content on the mechanical characteristics of rammed earth," Construction and Building Materials, vol. 54, no. 11, pp. 163-169, 2014.

[19] D. D. Tripura and K. D. Singh, "Characteristic properties of cement-stabilized rammed earth blocks," Journal of Materials in Civil Engineering, vol. 27, no. 7, Article ID 04014214, 2015.

[20] Chinese National Standard, "Methods for chemical analysis of cement," GB/T 176-2008, Standards Press of China, 2009 (Chinese).

[21] E. Fodde, K. Watanabe, and Y. Fujii, "Measuring evaporation distribution of mud brick and rammed earth," Structural Survey, vol. 32, no. 1, pp. 32-48, 2014.

[22] GB/T 50123-1999, Standard for Soil Test Method, China Planning Press, Beijing, China, 1999 (Chinese).

[23] L. Denaix, F. Van Oort, M. Pernes, and A. G. Jongmans, "Transmission X-ray diffraction of undisturbed soil microfabrics obtained by microdrilling in thin sections," Clays and Clay Minerals, vol. 47, no. 5, pp. 637-646, 1999.

[24] L. B. Liao and G. W. Li, Methods and Application of X-Ray Diffraction, Geology Publishing House, 2008 (Chinese).

[25] J. J. Xin, X. H. Wang, and H. Gu, "Application of EDS spatial difference method to grain boundary analysis in $\mathrm{SrTiO}_{3}$-based ceramics," Journal of Chinese Electron Microscopy Society, vol. 27, no. 1, pp. 5-9, 2008 (Chinese).

[26] GB/T 17359-2012, General Specification of X-Ray EDS Quantitative Analysis for EPMA and SEM, Standards Press of China, 2012 (Chinese).

[27] ASTM International, "Standard performance specification for hydraulic cement," ASTM C1157 / C1157M-11, ASTM International, West Conshohocken, Pa, USA, 2011.

[28] ASTM, "Standard specification for blended hydraulic cements," ASTM C595/C595M-15e1, ASTM International, West Conshohocken, Pa, USA, 2015.

[29] JTG E40-2007, Test Method of Soils for Highway Engineering, China Communications Press, Beijing, China, 2007 (Chinese).

[30] N. Agnew, F. Preusser, and J. R. Druzik, "Strategies for adobe preservation-the getty conservation institute research program," in Proceedings of 5th International Meeting of Experts on the Conservation of Earthen Architecture, pp. 3-11, Rome, Italy, October 1987.

[31] Z.-X. Li, M.-S. Shao, and R. Chen, "Impact of PS on permeability of unsaturated ruins clay," Rock and Soil Mechanics, vol. 32, no. 7, pp. 2039-2044, 2011.

[32] G. Van De Genachte, D. Mallants, J. Ramos, J. A. Deckers, and J. Feyen, "Estimating infiltration parameters from basic soil 
properties," Hydrological Processes, vol. 10, no. 5, pp. 687-701, 1996.

[33] D. K. Chattopadhyay, S. S. Panda, and K. V. S. N. Raju, “Thermal and mechanical properties of epoxy acrylate/methacrylates UV cured coatings," Progress in Organic Coatings, vol. 54, no. 1, pp. 10-19, 2005.

[34] D. Rosu, C. N. Cascaval, and L. Rosu, "Effect of UV radiation on photolysis of epoxy maleate of bisphenol A," Journal of Photochemistry and Photobiology A: Chemistry, vol. 177, no. 23, pp. 218-224, 2006.

[35] C. Beckett and D. Ciancio, "Effect of compaction water content on the strength of cement-stabilized rammed earth materials," Canadian Geotechnical Journal, vol. 51, no. 5, pp. 583-590, 2014.

[36] V. Sharma, H. K. Vinayak, and B. M. Marwaha, "Enhancing compressive strength of soil using natural fibers," Construction and Building Materials, vol. 93, pp. 943-949, 2015.

[37] E. Quagliarini and S. Lenci, “The influence of natural stabilizers and natural fibres on the mechanical properties of ancient Roman adobe bricks," Journal of Cultural Heritage, vol. 11, no. 3, pp. 309-314, 2010.

[38] A. Aldaood, M. Bouasker, and M. Al-Muzahim, "Impact of freeze-thaw cycles on mechanical behavior of lime stabilized gypseous soils," Cold Regions Science and Technology, vol. 99, no. 1, pp. 38-45, 2014.

[39] L. Li, M. Shao, S. Wang, and Z. Li, "Preservation of earthen heritage sites on the Silk Road, northwest China from the impact of the environment," Environmental Earth Sciences, vol. 64, no. 6, pp. 1625-1639, 2011.

[40] Y. M. Wang, G. P. Sun, W. W. Zhan, and L. Ding, "Strength characteristic of sand fixated by SH," Chinese Journal of Rock Mechanics and Engineering, vol. 22, no. 2, pp. 2883-2887, 2003 (Chinese).

[41] M. L. Sun, X. D. Wang, and Z. X. Li, "Issues concerning earthen sites in northwest China," Journal of Lanzhou University (Natural Sciences), vol. 46, no. 6, pp. 41-45, 2010.

[42] S. Zamani and M. Mahmoodabadi, "Effect of particle-size distribution on wind erosion rate and soil erodibility," Archives of Agronomy and Soil Science, vol. 59, no. 12, pp. 1743-1753, 2013.

[43] G. G. Hunter and I. H. Lynn, "Wind erosion of a soil in north Canterbury," New Zealand Journal of Experimental Agriculture, vol. 16, no. 2, pp. 173-177, 1988.

[44] Q. B. Bui, J. C. Morel, B. V. Venkatarama Reddy, and W. Ghayad, "Durability of rammed earth walls exposed for 20 years to natural weathering," Building and Environment, vol. 44, no. 5, pp. 912-919, 2009.

[45] N. Degirmenci and B. Baradan, "Chemical resistance of pozzolanic plaster for earthen walls," Construction and Building Materials, vol. 19, no. 7, pp. 536-542, 2005.

[46] R. Illampas, I. Ioannou, and D. C. Charmpis, "Overview of the pathology, repair and strengthening of adobe structures," International Journal of Architectural Heritage, vol. 7, no. 2, pp. 165-188, 2013.

[47] M. A. Bello, L. Martin, A. Martin, and R. N. Butlin, "Scanning electron microscopy to establish the marble weathering mechanism in the Alhambra of Granada," Scanning Microscopy, vol. 5, no. 3, pp. 645-652, 1991 (Spanish).

[48] W. W. Chen, Z. Q. Guo, Y. R. Xu, P. F. Chen, S. Zhang, and F. Ye, "Laboratory tests on rammed earth samples of earthen sites instilled by reinforcement material SH," Chinese Journal of Geotechnical Engineering, vol. 37, no. 8, pp. 1517-1532, 2015 (Chinese).
[49] X.-J. Li, J.-H. Lin, T. Wan, and W.-B. Xiao, "The preparation of a new consolidation material for earthen archaeological site and the evaluation of its effectiveness," Journal of Chengdu University of Technology, vol. 33, no. 3, pp. 321-326, 2006. 

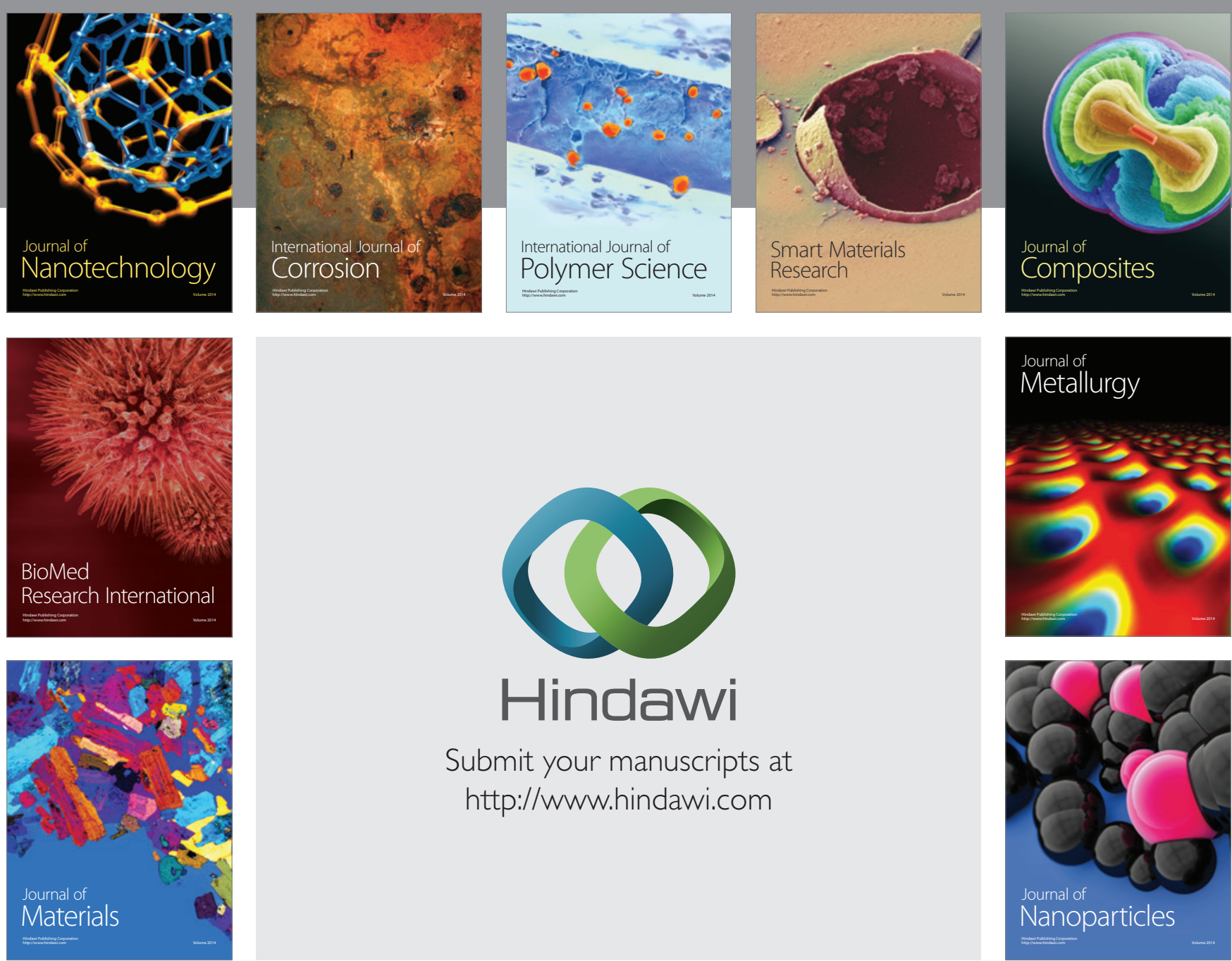

\section{Hindawi}

Submit your manuscripts at

http://www.hindawi.com

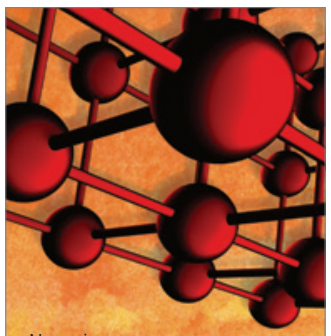

Materials Science and Engineering
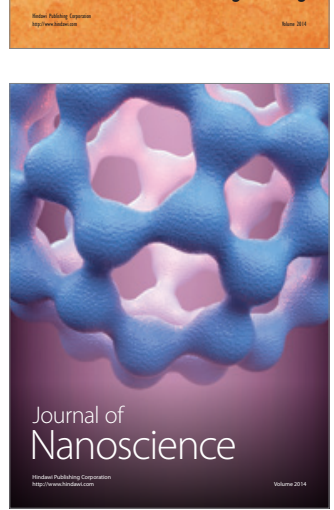
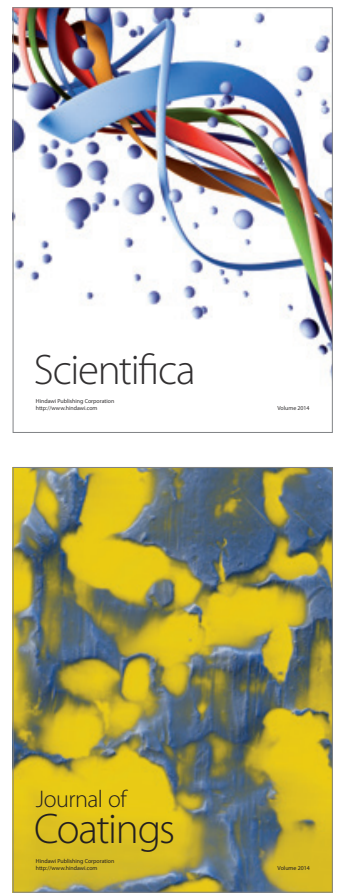
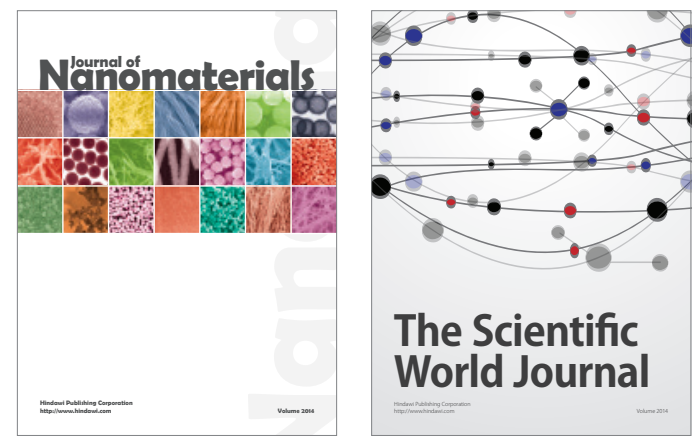

The Scientific World Journal
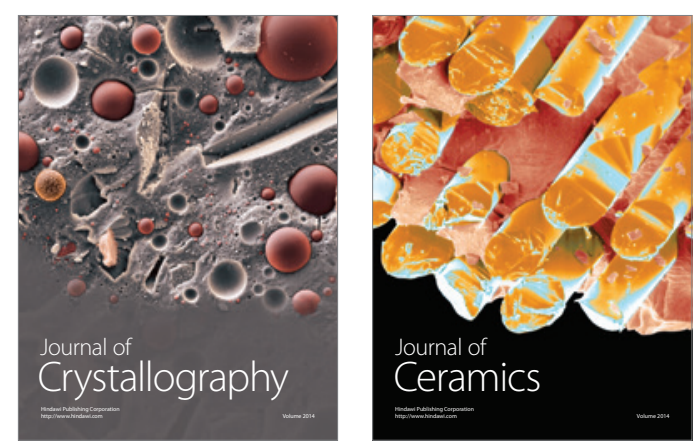
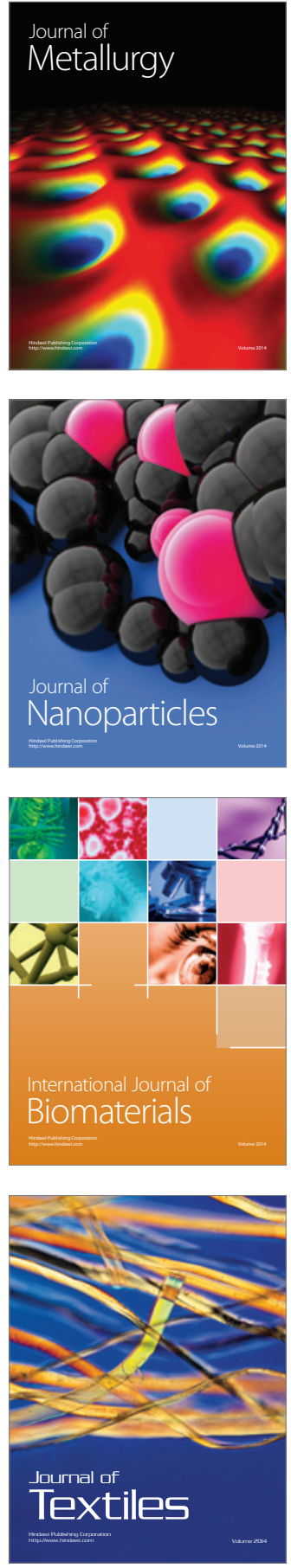